Article

\title{
Pregnancy, Childbirth and Nursing in Feminist Dystopia: Marianne de Pierres's Transformation Space (2010)
}

\author{
Jessica Aliaga-Lavrijsen (D) \\ Department of English and German Philology, Faculty of Philosophy and Letters, University of Zaragoza, \\ Pedro Cerbuna, 12, 50009 Zaragoza, Spain; jeskeal@unizar.es
}

Received: 15 May 2020; Accepted: 2 July 2020; Published: 7 July 2020

\begin{abstract}
Marianne de Pierres's Transformation Space (2010) is a rare example of an Australian novel set in an apocalyptic and dystopic interstellar future where pregnancy, childbearing and nursing have a presence that is quite uncommon in Science Fiction (SF). Despite the fact that the genre of SF and that of space opera in particular have been traditionally quite male-oriented, in the last years feminist theories of several kinds have been an undeniable transformative influence. This article intends to analyse not only how these specifically female issues related to motherhood/mothering are presented in the novel, but also to explore their function and role. A close reading of these topics will show whether they endorse a solid feminist stance or are just colourful feminist details in a male-dominated space opera and, in turn, if they have a specifically narrative purpose in the context of the dystopic subgenre.
\end{abstract}

Keywords: childbirth; contemporary Australian literature; dystopic novel; feminism; feminist SF; nursing; pregnancy; Science Fiction; space opera

\section{Introduction}

In general terms, it could be argued that most Science Fiction (SF) is firmly masculine, even misogynist, and that it is deeply connected to colonialist discourse. Women SF writers have been considered to be "very rare" creatures, "at first [they were even] believed to be mythological" (Le Guin 1993, p. 228). In particular, space operas-which have been defined as "action-adventure stories of interplanetary or interstellar conflict" (Clute and Nicholls 1993, p. 1138) ${ }^{1}$ as they are fully packed with action, spaceships and wars-have traditionally dealt with masculine and competitive issues, completely ignoring human processes such as reproduction, pregnancy and childbirth. As a matter of fact, SF works that focused on female preoccupations and interests, as well as on the impact of new technology and science on women's lives, were soon and unkindly labelled as 'diaper fiction' in the 1950s (Yaszek 2006, p. 76). As this malicious designation suggests, many (male) readers and critics $^{2}$ seemed to believe that issues such as child-rearing were more typical of women's magazine fiction than of SF, and that, by including these elements, they "would ruin the real imaginative fun of the [SF] genre stories" (Yaszek 2006, p. 91).

Fortunately, in the last decades there has been a pluralisation of ideologies in the genre of SF, and we can come across a number of feminist approaches to topics that had so far been considered to be

1 For a detailed account of the evolution of the "hacky, grinding, stinking, outworn, spaceship yarn" subgenre from the 1920s onwards, see Clute et al. (2020) and Winter (2016).

2 Some feminist critics such as Pamela Sargent, who coined the term 'housewife heroine SF' also seemed to perceive that the more domestic-oriented SF stories were 'silly' (Yaszek 2006, pp. 91-91). 
classically male, such as the conquest of outer space, time travel—or the mastering of time-intergalactic conflict and extraplanetary trade expansion, among others (Aliaga-Lavrijsen 2019, p. 59). However, as Lisa Yaszek contends, "SF was never about boys and their toys" (Yaszek 2018, p. ix), as "women have been involved in shaping SF all along" (xi). Yet, it cannot be denied that women in SF have met a lot of resistance, as in many other fields of art and real life. Despite the growing presence of women SF writers and of SF feminisms, patriarchy and misogynist ideologies are still operative, and sexism is still nowadays as discernible in the genre as before. ${ }^{3}$

A primary concern of 'sf feminisms' ${ }^{4}$ since the 1970 has been the thorough questioning of "the masculinist discourses of traditional science fiction" and the breaking down of "universalist assumptions about gendered identities" (Baccolini 2000, p. 16). As Baccolini further contends, the dialectical engagement with tradition that authors such as Anne McCaffrey, Joanna Russ, Ursula K. Le Guin, Alice Sheldon (James Tiptree Jr.), Marge Piercy and Octavia Butler have established has in turn given way to new genres such as "'open or critical dystopia,' which seems to be the preferred genre of the 1980s and 1990s" (Baccolini 2000, p. 16). In contrast to 'classical dystopias', in which there is little space for optimistic outcomes, critical dystopias "allow readers [ ... ] to hope by resisting closure [and] maintain the utopian impulse within the work" (Baccolini and Moylan 2006, p. 7). By examining patriarchal and colonial societies, these works "can aid readers in moving towards change" (Stankow-Mercer 2009, p. 91).

More particularly, the subgenre of feminist dystopia ${ }^{5}$ —inaugurated by Rose Macaulay's What Not (Macaulay 1918) and to be followed by Charlotte Haldane Man's World (Haldane 1926), Cicely Hamilton's Lest Ye Die (Hamilton 1928), Naomi Mitchison's We Have Been Warned (Mitchison 1935) and Katherine Burdekin's Swastika Night (Burdekin 1937), among others-usually warns against the harmful consequences of patriarchy, and questions its political and/or moral theory by depicting a future in which this ideology grounds the systemic oppression of the female sex by the male sex (Little 2007, p. 16). This genre "specifically addresses gender ideologies and issues, and often uses current social conditions to show the sexism inherent in societies that follow a patriarchal model" (Stankow-Mercer 2009, p. 91). Hence, in a sense it could be argued that these novels are projections of past and present misogynistic realities. As Judith A. Little has pointed out, feminist SF dystopias "imaginatively mirror actual abominable treatment of women" (Little 2007, p. 16). This is the reason why many feminist dystopic novels specifically and also explicitly deal with sexual violence, forced reproduction, pregnancy, abortion, ectogenesis, reproductive control and gender roles from different feminist perspectives, which sometimes hold opposing opinions on some of these issues.

Perhaps the most controversial or debatable topic dealt with in these novels is motherhood/mothering, as the several feminisms included under the umbrella term 'radical feminism' have often shown divergent perspectives on it. As Rich (1976) has noted, 'motherhood' can be interpreted and experienced as a patriarchal institution, as opposed to 'mothering', which would be female-defined and centred, and which she understands as a female empowering experience. On the one hand, following Rich's distinction we find some feminist thinkers, such as Firestone (1970), Allen (1984) and Stanworth (1987), who perceive motherhood as a biological trap for women and as building up the very basis for gender inequality. In this line of thought, ectogenesis ${ }^{6}$ would appear as a technological liberating tool that would free "women from the tyranny of their reproductive biology"

3 This is made patent in controversies such as the one surrounding the 2015 Hugo Awards, in which a "block of male authors [ ... ] manipulated the nomination process in order to eliminate novels perceived by them as being too focused on social and political messaging (including feminism)" (Boshoff 2017, p. 4).

4 Helen Merrick uses the term "sf feminisms" rather than "feminist sf" because the former includes a variety of communities and generations that the later does not (Merrick 2009, p. 9).

5 It was John Stuart Mill who coined the world 'dystopia' in 1868, but it was not until the turn of the nineteenth century that the dystopian literary genre began to flourish, when many visionary utopic narratives started showing fear and anxieties of control (Gidley 2017, p. 17).

6 For a more detailed account of ectogenesis and its representation in feminist SF literature, see (Aliaga-Lavrijsen 2021). 
(Firestone 1970, p. 301). On the other hand, we find the contrasting view held by thinkers such as Andrea O'Reilly, who defend the possibility or potentiality of feminist mothering and advocate the need to support 'matricentric feminism' (O'Reilly 2016). In short, while motherhood as an institution is a male-defined site of oppression, women's own experiences of mothering can nonetheless become a source of power (O'Reilly 2014, n.p.), hence the importance of analysing the representation of these topics in depth.

Marianne de Pierres's Transformation Space is an uncommon example of a feminist new space opera set in an apocalyptic and dystopic future where pregnancy, childbirth and nursing have a presence that is normally absent in the genre of SF. For this reason, it will be the aim of this paper to analyse how these specifically female issues related to motherhood/mothering are presented in the text, together with their function and role in it. A close reading of the novel will reveal whether these topics offer a feminist stance in a male-dominated and futuristic atmosphere, and if they have a specifically narrative purpose in the context of the subgenre.

\section{Marianne de Pierres's Transformation Space}

Marianne de Pierres holds a strong interest for feminist fiction, which earned her the 2014 Curtin University Distinguished Australian Alumni Award for "significant and valuable contributions to society in recognition of her feminist speculative fiction" (Landeese 2016, n.p.). She claimed to have been influenced by the works of female speculative fiction writers such as Octavia Butler, Sheri S. Tepper and Nancy Kress, as well as Le Guin (Boshoff 2017, p. 276). Furthermore, in her PhD de Pierres asserts that "certain female speculative fiction authors imagine future feminism in their work" (Landeese 2016, n.p.), so it becomes evident that she is very much aware of theories of cyber feminism and post-feminism, as well as the work of other feminist SF authors.

Roslyn Weaver labels de Pierres as a post-colonial feminist writer, central to apocalyptic Australian science fiction (Weaver 2011, pp. 164-86). Despite her popularity, however, de Pierres's work is a rarity in itself. As the author herself has commented in an interview, "I am probably Australia's best-selling female science fiction writer." There is a laugh before she continues: "Because there aren't many of us!" (Meacham 2011, n.p.). In Australia, she further states, "there is no culture that encourages female authors to write SF" (Boshoff 2017, p. 281). Besides, "female-authored SF can hit some obstacles with male readers' perceptions", so this is not the easiest genre to become a popular writer (Boshoff 2017, p. 282). Things are slowly changing, though, and as she goes on to explain, " $[\mathrm{t}$ ]oday, there's a whole range of women - and men — writing much more rounded female characters. Science fiction has become a better genre to read than it ever was" (Meacham 2011, n.p.). Indeed, female characters are no longer accessories to male-domineered plots, but they have instead become central figures in many SF and dystopic works.

This is definitely the case of De Pierres's The Sentients of Orion series, a new space opera with dystopic elements displaying many feminist concerns while showcasing a central, well-defined and active heroine, Mira Fedor. The subgenre of new space opera evolved at the same time as cyberpunk, and has been said to involve newer technologies, as well as rounder characterization. Michael Levy claims that this genre favours character development, high literary standards, verisimilitude and a moral exploration of contemporary social issues (Levy 2008, p. 132). Moreover, it puts special emphasis on ethics and how science and technology impact and affect civilisations. For this reason, it could be argued that the new space opera is closer to feminist SF than the 'old' space opera, traditionally regarded as an escapist and masculinist genre.

De Pierres creates empathy with the characters that she develops in her narrative (Wilson 2010, n.p.). This might be due to her construction of round and complex characters, together 
with her use of multiple viewpoints in the series ${ }^{7}$ to give fragmented and complementary perspectives. As de Pierres argued, "it was a very conscious decision to go to third person, multiple viewpoint [ ... ] I wanted Sentients to be complex and nuanced and tricky" (Pierce 2010, n.p.). The plot is thus structured around the different characters' viewpoints, together with those of the central figure and heroine.

In order to contextualise my analysis, I will briefly outline some of the most important elements in the plot. In Dark Space, the first book of The Sentients of Orion series, the setting is Araldis, a small mining planet ruled by a strongly male-oriented Machiavellian society, from which women try to "escape their repression by learning how to reverse the Latino male control over fertility" (de Pierres 2007, p. 198). Baronessa Mira Fedor is the first aristocrat to have been born with a gene that allows her to communicate directly with the biozoon creatures that control the spacecrafts (Burgess 2008, n.p.). Besides, she is also the first woman to have ever been born with this gift, which Principe Franco, the ruler of the planet, finds wholly unacceptable. When, at her graduation ceremony, it is announced that the gene will be transferred from Mira to Trinder Pelligrini, Prince Franco's son, Mira has no other choice but to escape (Burgess 2008, n.p.). Before she is forced to leave, Trinder Pelligrini sexually assaults her in order to keep his genetic line. Mira will get pregnant as a result of this violent act (de Pierres 2007, p. 368). In Mirror Space (de Pierres 2009), the third book of the series, Post-Species aliens conduct some genetic experiments on her unborn baby ${ }^{8}$ and, in the fourth, titled Transformation Space, Mira realizes that her gestation is taking place at an un-human pace (the extropists' procedures are having unforeseen effects on her unborn child). Her gender-neutral baby is born and, although Mira always refers to her as "she." This baby, whom Mira decides to name her Nova, will play a key role to prevent "the end of humanesque- and alien-kind" (344) and the destruction of the universe. In this fourth book, all the action, together with the outcome of the whole series, revolves around the figures of Mira Fedor and her child; pregnancy, childbirth and the first moments in the lives of mother and baby are remarkably highlighted.

The capacity to become a mother has been usually taken as one of the key signifiers of sexual difference and is thus a recurrent theme in feminist studies. Yet, the topic of motherhood/mothering is not very frequently tackled in SF. As Russ has stated, in many feminist SF texts addressing gender, child "bearing arrangements are never described" (Russ 2007, p. 25). As she further comments, "the women who appear in these stories are either young and childless or middle aged, with their children safely grown up" (Russ 2007, p. 25). The reason for this may have been the wish to escape the misogynist attacks against fiction that tackled these issues ('diaper fiction' was a case in point), or else the strong influence of the feminisms of the 1970s and 1980s, as put forward by critics such as Firestone, Rich and Allen, who concluded that pregnant women and mothers were, in a way, biologically trapped.

De Pierres's work will be an exception, ${ }^{9}$ as it clearly focuses on both the physical and emotional impact of pregnancy, birthing and nursing. As this analysis will show, the function of these elements is twofold: On the one hand, they allow for the representation of female issues in a male-controlled environment, whose setting is that of most space operas, namely, spaceships and intergalactic territories. On the other hand, they carry out a feminist reading and critique of female processes in patriarchally controlled and constructed situations.

\subsection{Pregnancy}

Transformation Space opens with Mira desperately protecting the vulnerable foetus so rapidly growing within her (Meacham 2011, n.p.): Mira "had begun to lose her pregnancy waters in the

7 Dorothea Boshoff argues that The Sentients of Orion series conforms to the characteristics of "new space opera" in its cyberpunk element of political commentary, but also "in its detailed characterisation and its move away from the 'chauvinism' present in original space opera" (Wolfe 2014, p. 67).

8 The experiments carried out by the extropists, which might bring to mind the genetic manipulations performed by the Oloi in Octavia E. Butler's Dawn (Butler 1987), are in fact manipulations of the foetus' genetic material.

9 Another exception is the pioneering SF novel by Naomi Mitchison Memoirs of a Spacewoman (Mitchison 1962), in which the female main character has several hybrid children with various alien species. For more on this, see: (Aliaga-Lavrijsen 2020a). 
conference room on Intel station" and is seriously worried about her baby (de Pierres 2010, p. 6). As was argued before, her gestation is proceeding at an incredible speed due to the genetic mutations performed on the foetus. The baby conceived on Araldis, Mira explains, "is only a short time in the womb, and yet it wants to be born" (58). Furthermore, her biozoon believes "that the child is not properly humanesque" and that it is a Post-Species hybrid (58). The biozoon can control or take care of Mira up to a point, but it is not "able to stop the birthing process that has begun, only slow it down" (54). As Rene, one of the characters, explains, Mira's "circumstance ... her condition ... is complex and unusual" (57). It goes without saying that this not the most common situation on a spaceship.

The fact that there is no father figure is also addressed several times in the novel. Some characters, such as Rene, are asked if "the child" is theirs" (57), and Mira is questioned several times if "the father is alien" (58); if "the father was humanesque" (72); or directly "[w]ho was the father?" (300). Not surprisingly, in future outer space, prejudices about single mothers exist, too. In Mira's case this is especially painful, though; readers know that she got pregnant as a result of having been sexually assaulted by Trin.

There are certain elements related to sexual assault that might bring to mind the violence inflicted on Aboriginal women by white settlers. Mira is not only a strong heroine, but also a survivor of gender-based violence. As Boshoff and Byrne have stated, the novel "contains a trenchant critique of contemporary discourse about sexuality and sexual misconduct" (Boshoff and Byrne 2019, p. 89). The terrible abuse that Mira (like many Aboriginal women) experiences is portrayed as a not-uncommon event on the planet she comes from, Araldis, as well as on Orion. In Dark Space, the first novel in the Sentients series, "women are objectified and seen only as possessions, conquests or mild entertainment" (Boshoff and Byrne 2019, p. 92). They, like many Aboriginal women in the past, have been deprived of their power and freedom to reproduce. As is well known, not only did white settlers take absolute control of the Australian land, but they also sexually assaulted Aboriginal women at will, the outcome of which were the so-called "half-caste" children. ${ }^{10}$ To make matters worse, on account of the assimilationist policies enforced by the government many of these children, also called the Stolen Generation, were forcibly removed from their Aboriginal mothers to be taken to missions so that they could trained to become servants to white families. ${ }^{11}$

As was stated before, Trin sexually assaults Mira in order to impregnate her with his genes and make sure that his racial line continues. According to Boshoff and Byrne, "[t]here are distinct echoes here of the racist fear of miscegenation among colonialists by conceiving children with 'natives' and so contaminating the 'purity' of the racial line" (Boshoff and Byrne 2019, p. 96). Trin's obsession with genetic purity immediately brings to mind the forced sterilization that some Indigenous Australian women suffered, described by many as yet another act of genocide. Their body integrity was completely violated, while their psychic integrity became fully destroyed. Unfortunately, the effects and consequences of these acts can still be felt nowadays. ${ }^{12}$

The fact that Mira freely decides whether she wants to continue with her pregnancy or not and finally chooses to keep her baby is a clear sign of power and resistance against the patriarchal appropriation of the female body. Besides, the fact that her baby is a hybrid foetus and that she knows it also contributes to subverting Trin's fantasy of racial purity. Much to his regret, his genes will not be passed on 'pure.' This anxiety about racial mixing can be found in many SF stories of the 1920s

10 It must be said that this violence is not exclusive to the continent of Australia, and that many feminist dystopias "denounce the current onslaught on women's reproductive rights" and freedom all over the world (Martínez-Falquina 2019, p. 164).

11 Doris Pilkington's novella Follow the Rabbit-Proof Fence (Pilkington 1996), later on adapted for film as Rabbit-Proof Fence (Noyce 2002), is yet another text about this Stolen Generation. This is story of three half-breed girls who manage to escape the mission where they had taken after being wrenched from their mothers.

12 Actually, Indigenous women in Arnhem Land are still being sterilised without fully understanding the procedure and its implications (Indigenous News 2003, n.p.). 
and 1930s, when eugenics started to become popular. ${ }^{13}$ As Betsy Nies has argued, the rise of eugenics mirrored white male anxiety after WWI, and thus aimed at preserving white male privilege (Nies 2002, pp. xii-xiii). In many pulp stories, the fear of miscegenation and of the upsurge of a mixed race was represented on many occasions by interstellar human-alien relationships (Donawerth 2006, pp. 28-29). It is clear that de Pierres' series subverts and denounces the fear of miscegenation that can be found in many classic (patriarchal) SF stories, and which white male powerful characters in the novel so often show. Moreover, the fact that this hybrid child, unlike many half-breed children in Australia, is not wrenched from her family, but becomes instead the saviour of the galaxy, adamantly challenges the racist belief in the superiority of the pure (white) race.

As Mira arrives at hospital for specialized genetic research with her placenta breaking down (de Pierres 2010, p. 71), she feels "vulnerable lying on her back, covered by a translucent membrane and under the scrutiny of an array of sensors" (71). As a pregnant woman, she feels defenceless, she is in the lithotomy position and in the hands of a misogynous and racist man. Dolin, the clinician, "was like all the others who had come to examine the odd Latino woman carrying a child of indeterminate biology [and thus fatherhood]: curious but nursing a hint of faint repulsion beneath his spill-resistant research whites" (71). As is well known, the lithotomy position-with the mother lying on her back-is the most comfortable position for the clinician, but evidence suggests that the safest position, both for the mother and the baby, is the upright one. In addition, the World Health Organisation states "[i]t is important that any particular position is not forced on the woman and that she is encouraged and supported to adopt any position that she finds most comfortable" (WHO 2018, n.p.). The lithotomy position imposed on Mira increases her anxiety and frustration, and she is deeply worried about her baby: "She stared at the clinician in frustration. They' $\mathrm{d}$ all wanted endless details from her but were prepared to give only generalisations in return" (de Pierres 2010, p. 72). She feels that she is not given enough information about the risks that "the accelerator" might entail for the baby, and that she is been treated in a condescending way. Clearly, she does not feel in control of the situation.

\subsection{Birthing}

Doctors decide that the baby should be "born through the birth canal-not the normal procedure" (74). Mira refers to this "natural birth" as "uncontrolled birth" (74), making it clear that "natural birth was a rare thing" (75). Readers might deduce that the most common birth in this interstellar setting is through a caesarean section, an operation which should only be made in case of absolute necessity, as it can be a traumatic experience both for the mother and the baby. Although, at present, "caesarean sections have become increasingly common in both developed and developing countries" (WHO 2015, n.p.), according to the World Health Organisation they are "associated with short- and long-term risk which can extend many years beyond the current delivery and affect the health of the woman, her child, and future pregnancies" (WHO 2015, n.p.). The ultimate aim is, therefore, to try to lower the rate to $10 \%$ of births in favour of spontaneous labour and natural birth.

The fact that, in the novel, the most natural and beneficial way to give birth has become obsolete clearly points to the dangerously patriarchal nature of this society, in which obstetric violence has become the norm against the wellbeing of both women and babies. When Mira starts having contractions and is in the phase of active labour, doctors want to closely monitor the process: "Gloved hands reached through the bank of lights. 'Stay on your back. We must feel inside the birth canal"" (de Pierres 2010, p. 75). Nevertheless, Mira refuses, makes them go and asks for "women in attendance" (75). As Boshoff has argued, "de Pierres uses the male clinician to represent patriarchal control over and interference in women's bodies and reproductive processes" (Boshoff 2017, p. 91). For Mira, what feels most natural and safe is the help of a woman. Then, "a stocky woman dressed

13 Naomi Mitchison's Solution Three (Mitchison 1975) is an interesting example of a feminist SF novel tackling the issue of eugenics in depth. For more on this see: (Aliaga-Lavrijsen 2020b). 
in food-smeared overalls" comes to help her (de Pierres 2010, p. 76). Significantly, this improvised midwife-called Linnea-knows more about birth than doctors themselves. This can be inferred by her comment on the excess of light, which is known to inhibit the secretion of oxytocin, a hormone necessary for labour, "What're all these harsh lights for? For Scolar's sake ... men!" (76). Besides, Linnea addresses Mira with affection, rubs her back and even helps "her onto the floor, into a squatting position" (77). In short, she acts as the ideal midwife, still holding the ancient knowledge lost with the medicalization and technologization of childbirth in most parts of the galaxy. Linnea becomes "her beloved sister Faja" (79), which brings together all the important and strong women in Mira's life. This connection, moreover, allows Mira to gather enough strength to resist patriarchal power and give birth feeling protected.

Once Nova is born, however, the obstetric violence continues, as Mira is not allowed to hold her baby. As Linnea tells her, "Promised Dolin I'd put her straight in here [in the transparent crib], soon as I cut the cord. It's the only reason he let me in. Once the scan's done, yer can have her back" (79). Again, it is the male doctor who decides everything and who holds power, and both women feel powerless. "More clinicians arrived, crowding around the crib" even before Mira is given a chance to hold or see her baby (147). Finally, Linnea asks Mira how she intends to feed the baby, whom she names Nova, "[b]ecause she is new and fresh" (151). A healthy baby that the biozoon, Insignia, also considers to be hers, as she calls it "our child" (78, 80, 174, and 179).

\subsection{Nursing}

As soon as Mira is allowed to hold her baby, she feels "an overwhelming swell of emotion and responsibility" (147). She feels that "now she must ensure her survival" (147). De Pierres questions the patriarchal idea that all new mothers instinctively know what to do, which leads many insecure novice mothers to doubt their maternal abilities needlessly (Rich 1976, p. 1; Douglas and Michaels 2004, pp. 325-26). As Boshoff states, "the attention to the details of motherhood again come to the fore when Mira is unable to tell the midwife how she is planning to feed her baby" (Boshoff 2017, p. 93). It is clear that mothering is not something innate. For these reasons, we can conclude that the idea of motherhood presented in the novel is not based on the concept of biological determinism. In fact, and as was commented above, Insignia, the spaceship, also considers herself to be a mother to Nova. And, as we shall see, the link between the three women only becomes much stronger as the novel advances.

In this novel the idea of (patriarchally oppressive) motherhood is replaced by that of mothering, which has rather more positive and empowering connotations. Mira has the strength to confront patriarchal institutions as well as the powerful men who represent them. She does "not trust even Dolin to take the baby from her sight," and states that she "will be present during the tests" (de Pierres 2010, p. 148). Mira now appears to be stronger than before and, as the doctor suggests that she should have a rest while, they "take the child and feed" her, she strongly refuses by exclaiming: 'No!' [ ... ] 'I will feed her myself. And I will be present at the tests" (149), to then ask them to leave while she "acquaints [her]self with [her] daughter" (149).

Another situation that brings to the fore how motherhood and nursing have been culturally constructed is the fact that Mira does not know how to feed her baby at first- this was not something natural or common on planet Araldis-and she consequently asks Linnea to teach her "some mothering things" (148). Nursing may be innate in babies, but not in mothers, who have to learn it from other motherly figures. Despite its biological basis, nursing is not biologically determined, as it is also culturally grounded. As a matter of fact, race and ethnicity play an important role in successful breastfeeding. Although it is universally accepted in the medical field that breastfeeding is highly beneficial for both mother and child, women belonging to minority groups often run into additional obstacles. Many studies acknowledge that there is a racial divide as regards breastfeeding rates, and that minority groups, especially that of coloured mothers, have a significantly lower rate of nursing, despite the fact that "the benefits [of breastfeeding] may be significantly greater" for them 
(Jones et al. 2005, p. 187). The reason for this is a complex combination of legal, political and structural factors, which "impede black women's ability to breastfeed successfully" (Freeman 2015, p. 3057). In contrast, laws and regulations facilitate white mothers' breastfeeding, and popular culture glorifies it (Freeman 2018, n.p). Taking all of this into account, it can be argued that there is an implied critique against racism in the fact that Mira finds it difficult to breastfeed her baby. The act of nursing becomes an empowering act, not only against patriarchy, but also against exclusively white feminisms.

This being said, it is also true that Mira feels rather vulnerable when nursing: "The baby latched on and suckled without fussing. Mira's whole body relaxed with the movement of her tiny mouth, but with the release came an overpowering need to rest" (de Pierres 2010, p. 175). However, rest is difficult to get in the middle of a galactic war. Mothering apparently prevents her from doing what is necessary to save their lives-although later on readers will discover that it is precisely because she has given birth to Nova that they can all be saved. The novel is realistic in its representation of Mira as a motherly figure: she is tired and has to take care of her baby, in addition to attending to many other urgent matters. It is also true that she sometimes needs to delegate her care: "[t]he Primo vein had tended to all the baby's nutritional needs as they'd travelled, and dealt with her wastes" (202). In a sense, Primo is like a technological doula, helping her in the mothering process: "Mira's breasts, though heavy, were not dangerously engorged. Primo had gently massaged and drained milk from her to keep them healthy and functioning" (202).

Mira also realizes that there is something different in her baby: being alien altered, she has some "unusual characteristics," as the doctor explains (147). She is unnaturally alert (151). Furthermore, the "baby doesn't have reproductive organs of either sex" (151) as she is "neither male nor female" (154). This is something that Mira "could deal with," as biological sex was not something that could bother her. Neither does this bother Insignia, who also believes that this was "[a]rbitrary and unimportant. Nova is healthy; that is all that matters" (154, original emphasis). The biozoon knows this because "Nova has explained it" to her telepathically (154). It seems that the baby has inherited her special gene, as she has been communicating telepathically with Insignia since she was in the womb.

As Boshoff has pointed out, "[b]y ascribing gender-neutrality to Nova, who is benign (in contrast to the destructive Post-Species [ ... ]), de Pierres portrays the positive aspects of gender fluidity as opposed to highlighting the threat it holds (de Pierres 2007, p. 240). Despite the fact that she is neither male nor female, though, Mira feels comfortable using the pronoun "she" (de Pierres 2010, p. 154). As Boshoff goes on to say:

de Pierres uses gender reversal but not in the traditional sense of matriarchal utopia or dystopia. Instead of a society ruled by women, as in Charlotte Perkins Gilman's Herland (Perkins Gilman 1915) or Leslie F. Stone's The Conquest of Gola (Stone 1931), her inclusion of the trope appears in a number of different plot lines, for example the lack of gender and the lack of gender recognition in Insignia. (Boshoff 2017, p. 247)

Personally, I believe that by choosing the pronoun 'she' Mira is getting rid of all the patriarchal burdens she has suffered, from her sexual assault to obstetric violence, among other negative life experiences on Araldis. Nova represents not so much a genderless being, but rather a being freed from the burdens of gender biases. She symbolizes a new beginning outside the realms of patriarchy. This sense of new beginning and (feminist) hope is emphasized by the role she plays in the final denouement of the novel.

\section{Nova, or Hope in a Patriarchal Dystopia}

On Araldis, Mira's native planet, we find a backwater society in which men hold all the power. This, as Burgess has pointed out, "is certainly an interesting post-feminist reprisal of look-how-far-we've-come type fiction" (Burgess 2008, n.p.). As has been shown, this patriarchal society is very repressive towards women. Among other things, "Mira has no control over her fertility," as only men can decide when a woman should be impregnated (Meacham 2011, n.p.). 
Nevertheless, although Mira's pregnancy is the result of a traumatic sexual assault-thus echoing Octavia Butler's character Lilith, who is sexually assaulted to engender the first Oankali-human child, Akin (Butler 2000, p. 246) — she loves the baby growing inside her and will do anything to protect it, so strong is their in-womb bonding. According to Boshoff, "Nova is not only a new being heralding a new beginning after the trauma of Mira's sexual assault; the child is also a new type of humanesque and embodies gender innovation" (Boshoff 2017, p. 240). She thus encapsulates the possibility of a new and fresh beginning in a world that is bound to disappear, since a gigantic Post-Species Saqr ship is going to exterminate all known life (de Pierres 2010, p. 384).

As was stated before, Nova can communicate telepathically with Insignia: "Mira struggled to assimilate the fact that her infant was able to communicate with Insignia [ ... ]. It should be impossible. It should" (182, original emphasis). Yet, her daughter's special assets suggest that she can make the impossible possible. The connection they had in the womb is now shared by Insignia as well; the three of them have become an interconnected entity, a family with "a telepathic bond" (199). The strong sense of communion concomitant with the process of mothering has been extrapolated to this woman-hybridchild-machine triad. The three of them partake of this communal mothering act. The novel as a result becomes trans-inclusive, as it opens feminism to the consideration of non-biologically determined aspects. With the passing of time, Nova evolves and becomes much more active. Her (telepathic) language becomes more complex and she starts taking decisions. At a certain point, Mira finds out that Nova was actually helping her even before she was born: "You helped me?" (253). The three of them take care of one another. There is no unique figure looking after the rest, but instead, the three of them make up a web of mutual responsibility and care.

As the novel reaches its climax and thousands of Post-Species Saqr crafts attack, Nova's role becomes crucial. Mira and her "newborn child" are the only ones who can prevent the destruction of everything known. As Mira connects with Insignia, she can see a "sea of horror and destruction" (343). The end of the universe is near:

The dust of imploded worlds seemed to coat her, the screams of the dying twisted her stomach, and the dryness of the solar winds parched her mouth. She was there, witnessing the end of family dynasties, the disfiguration of whole planetary systems, the sudden and profound snuffing out of billions and billions of lives. (343)

Despite the horror she contemplates, Mira can still have a glimpse of hope: "[t]he scale of annihilation became incomprehensible, and yet among it she saw faint shafts of hope" (343). Then, her daughter projects "a wave of electromagnetic rebuke" slamming the Post-Species ship and repelling the attack (385). However, it is not through violence that she wins the battle, but by means of (telepathic) dialogue with "The Entity" who is leading the attack. Nova is able to establish real contact with it and convince it not to destroy the universe. She speaks to it about loneliness, sharing "a grave melancholia, a vast emptiness without end" (387). To this the Entity replies that "in death there is life" (388), and that life always comes from destruction and extinction: "And she saw it, the life energy from billions and billions of dead sentients released into space, combining with matter, colliding and transforming into dark energy" (389). The idea that life comes from destruction is, to say the least, controversial, all the more so if we look at it from a postcolonial perspective. Yet, if we regard Transformation Space as a feminist and postcolonial critical dystopia rather than as a classical one, and focus instead on its hopeful ending, it becomes clear that racialized women, together with mixed-race children, as represented by Mira and Nova, can "invent a new world in which to challenge and change dominant cultural constructions for widely differing agendas" (Weaver 2011, p. 136). As Rosyln Weaver argued with regard to Australian apocalyptic fiction, "[ $t$ ]he apocalyptic paradigm of revelation and disaster can work effectively to interrogate the history of colonization and relations between white and Indigenous Australians" (136). This somehow questions the idea that apocalypse is, by definition, "a quintessentially male product" (Keller 1996, p. 28), full of "toxic misogyny" (29), in which violence is the central engine to enable the persecution of minority groups and the subordination of women (Goldman 2005, pp. 25-26). 
In de Pierres's novel, apocalyptic dystopia becomes an opportunity to re-inscribe marginal figures as significant agents in a future improved world, (maybe) free of patriarchal and colonialist forces. Nova embodies hope amidst destruction, she becomes the saviour of the humanesque and the alien, the creator of the new. Similarly, the figure of her hybrid child represents a bright future, a new redemptive beginning. As has been seen, the apocalyptic and dystopic mode, which is experiencing a new surge in the last decades (Watkins 2020, p. 4), is ideologically charged, as it is increasingly tackling specific concerns of people living in particular places (Kermode 1968, p. 57). In Transformation Space, the apocalypse is imagined and represented from a feminist perspective by incorporating pregnancy and birth — that is, the beginning of life as created in the female body-as its main issues. According to Rebekah Sheldon, the figure of the child should be seen "as the recipient of a specific biological inheritance freighted with consequence for the future" (Sheldon 2016, p. 3). It is not a blank slate, as it is inscribed into "a story of generational succession and lineage" (3). Nova is Mira's daughter, the child resulting from a sexual aggression to be later on genetically altered by the post-Species. However, it is by no means "mechanistically determined by biological imperatives" (3). Nova, as her name suggests - 'new' in Latin-means a new beginning for all, a beginning that might start with an astrological explosion, as so happens in the novel. ${ }^{14}$

\section{Conclusions: There is Hope in Feminist Dystopia}

In conclusion, de Pierres's novel contributes to fostering ongoing conversations about maternity, gender and patriarchy in SF. By focusing on Mira's pregnancy, de Pierres's new space opera reveals itself as clearly feminist, postcolonial and non-escapist. Mira's mothering processes are female-defined and centred, and her pregnancy can be interpreted as an act of power and resistance against the patriarchal appropriation of the female body. As this analysis has shown, the representation of pregnancy, birthing and nursing in Transformation Space has a twofold function: on the one hand, it allows for the representation of female issues in such a masculine genre as $\mathrm{SF}$, and the subgenre of space opera in particular. On the other, it launches a feminist critique against the violence inflicted on female biological processes that are usually under the control of powerful patriarchal institutions and societies.

After examining the representation of the maternal issues of pregnancy, childbirth and nursing in the novel, together with the role played by the main female heroine and her daughter, it can be concluded that they are lot more than merely feminine elements in a male-dominated world. The analysed topics function as a clear feminist and postcolonial critique of patriarchal ideology, especially as regards reproduction and childbearing. As has become evident, the idea of (patriarchally oppressive) motherhood is replaced in the novel by that of 'mothering,' which entails rather more positive and empowering connotations. Despite all the difficulties that the single pregnant Latino mother has to face, Mira is able to come out triumphant and empowered. Besides, her hybrid and gender-neutral child embodies the positive aspects of gender fluidity: she is free from the burdens of gender biases, and in turn undermines racism and the fear of miscegenation.

Last but not least, the positive role played by the heroine, together with the empowering relationship she has with Nova, allow de Pierres's novel to provide some hope in a dystopic and patriarchal universe. These female characters are able to overcome violence in order to be the agents of their own stories and build up their own futures. Furthermore, this novel offers an alternative to classical dystopia: the birth of Nova has a specific narrative purpose in the context of this dystopic/ apocalyptic novel; by saving the universe, she symbolizes a possible rebirth ${ }^{15}$ in a dying world. Nova

14 Astronomer Tycho Brahe observed a new star in 1572, described in his book De nova stella (Brahe 1573).

15 In similar lines, Dolores Herrero analyses the power of women's agency as providing some hope of rebirth in dystopian Australian tradition (Herrero 2017). 
is the very beginning at the very end, the new blood in a decaying and oppressive universe so well represented by male-dominated space opera and SF.

Funding: The research carried out for the writing of this article is part of a project financed by the Spanish Ministry of Economy, Industry and Competitiveness (MINECO) in collaboration with the European Regional Development Fund (DGI/ERDF) (code FFI2017-84258-P).

Acknowledgments: The author is also thankful for the support of the Government of Aragón and the European Social Fund (ESF) (code H03_17R).

Conflicts of Interest: The author declares no conflict of interest.

\section{References}

Aliaga-Lavrijsen, Jessica. 2019. A Feminist Perspective on the End of Humanity: P. D. James' The Children of Men. International Journal of Humanities and Social Science Invention (IJHSSI) 8: 59-63.

Aliaga-Lavrijsen, Jessica. 2020a. A Transmodern Approach to Biology in Naomi Mitchison's Memoirs of a Spacewoman. In Transcending the Postmodern. The Singular Response of Literature to the Transmodern Paradigm. Edited by Susana Onega and Jean Michel Ganteau. New York: Routledge, pp. 213-30.

Aliaga-Lavrijsen, Jessica. 2020b. Naomi Mitchison's Solution Three or the Need for Biological and Cultural Difference. In L'Ecosse: la différence/Scotland: The Difference. Edited by Sabrina Juillet. Besançon: Presses Universitaires de Franche-Comté, in print.

Aliaga-Lavrijsen, Jessica. 2021. Reproductive Technology and New Motherhood(s) in Helen Sedgwick's. The Growing Season. In process.

Allen, Jennifer. 1984. Motherhood: The Annihilation of Women. In Mothering: Essays in Feminist Theory. Edited by Joyce Trebilcot. Totowa: Roman and Allanheld, pp. 315-30.

Baccolini, Raffaella. 2000. Gender and Genre in Feminist Critical Dystopias. In Future Females, The Next Generation. New Voices and Velocities in Feminist Science Fiction Criticism. Edited by Marleen S. Barr. Lanham: Rowman \& Littlefield Publishers, pp. 13-34.

Baccolini, Raffaella, and Tom Moylan. 2006. Dark Horizons: Science Fiction and the Dystopian Imagination. New York: Routledge.

Boshoff, Dorothea. 2017. Crafting Positions: Representations of Intimacy and Gender in The Sentiments of Orion. Ph.D. dissertation, University of South Africa, Pretoria, South Africa. Available online: http: //uir.unisa.ac.za/bitstream/handle/10500/23473/thesis_boshoff_a.pdf?sequence=1\&isAllowed=y (accessed on 1 June 2020).

Boshoff, Dorothea, and Deirdre C. Byrne. 2019. "He Said, She Said: Fake News and \#MeToo in Marianne de Pierres' Sentients of Orion". In Messengers from the Stars: On Science Fiction and Fantasy. Edited by Danièle André and Christopher Becker. vol 4, pp. 88-102. Available online: http://messengersfromthestars.letras.ulisboa.pt/ journal/ (accessed on 4 July 2020).

Brahe, Tycho. 1573. De nova Stella et Nullius Aeri Memoria Primus Visa. Copenhagen.

Burdekin, Katherine. 1937. Swastika Night. London: Victor Gollancz Ltd.

Burgess, R. J. 2008. Review: Dark Space by Marianne de Pierres. Strange Horizons. April 21. Available online: http://strangehorizons.com/non-fiction/reviews/dark-space-by-marianne-de-pierres/ (accessed on 7 March 2020).

Butler, Octavia E. 1987. Dawn. New York: Warner Books.

Butler, Octavia E. 2000. Lilith's Brood. New York: Central.

Clute, John, and Peter Nicholls. 1993. The Encyclopedia of Science Fiction. New York: St Martin's Griffin.

Clute, John, David Langford, Peter Nicholls, and Graham Sleight. 2020. Space Opera. SFE. The Encyclopedia of Science Fiction. Available online: http://www.sf-encyclopedia.com/entry/space_opera (accessed on 10 April 2020).

de Pierres, Marianne. 2007. Dark Space. The Sentients of Orion, Book One. London: Orbit. de Pierres, Marianne. 2009. Mirror Space. The Sentients of Orion, Book Three. London: Orbit.

de Pierres, Marianne. 2010. Transformation Space. The Sentients of Orion, Book Four. London: Orbit, Kindle edition. 
Donawerth, Jane. 2006. Illicit Reproduction: Clare Winger Harris's 'The Fate of Posidonia'. In Daughters of the Earth. Feminist Science Fiction in the Twentieth Century. Edited by Justine Larbalestier. Middletown: Wesleyan University Press, pp. 20-35.

Douglas, Susan J., and Meredith W. Michaels. 2004. The Mommy Myth: The Idealization of Motherhood and How it has Undermined Women. New York: Free Press.

Firestone, Shulamith. 1970. The Dialectics of Sex: The Case for Feminist Revolution. New York: Morrow.

Freeman, Andrea. 2015. 'First Food' Justice: Racial Disparities in Infant Feeding as Food Oppression. Fordham Law Review 83: 3053-87. Available online: https://ir.lawnet.fordham.edu/cgi/viewcontent.cgi? article=5112\& context=flr (accessed on 2 May 2020).

Freeman, Andrea. 2018. U.S. Support of Formula over Breastfeeding is a Race Issue. The Conversation. July 24. Available online: https://theconversation.com/u-s-support-of-formula-over-breastfeeding-is-a-race-issue99987 (accessed on 2 May 2020).

Gidley, Jennifer M. 2017. The Future: A Very Short Introduction. Oxford: Oxford University Press.

Goldman, Marlene. 2005. Rewriting Apocalypse in Canadian Fiction. Montreal: McGill-Queen's University Press.

Haldane, Charlotte F. 1926. Man's World. London: Chatto and Windus.

Hamilton, Cicely. 1928. Lest Ye Die: A Story from the Past or of the Future. New York: Charles Scribner's Sons.

Herrero, Dolores. 2017. Post-Apocalypse Literature in the Age of Unrelenting Borders and Refugee Crises Merlinda Bobis and Australian Fiction. Interventions 19: 948-61. [CrossRef]

Indigenous News. 2003. Aboriginal Women Sterilised without their Consent: Report. December 5. Available online: https://www.abc.net.au/news/2003-12-05/aboriginal-women-sterilised-without-their-consent/101008 (accessed on 11 June 2020).

Jones, Katherine M., Michael L. Power, John T. Queenan, and Jay Schilkin. 2005. Racial and Ethnic Disparities in Breastfeeding. Brestfeeding Medicine 10: 186-96. [CrossRef] [PubMed]

Keller, Catherine. 1996. Apocalypse Now and Then: Feminist Guide to the End of the World. Minneapolis: Augsburg Fortress Publishers.

Kermode, Frank. 1968. The Sense of an Ending. Studies in the Theory of Fiction. Oxford: Oxford University Press.

Landeese, Ju. 2016. 2016 Snapshot: Marianne de Pierres. Australian SF Snapshot Project. Available online: https: //austsfsnapshot.wordpress.com/tag/marianne-de-pierres/ (accessed on 3 April 2020).

Le Guin, Ursula K. 1993. The Language of the Night: Essays on Fantasy and Science Fiction. New York: Perennial.

Levy, Michael. 2008. Cyberpunk Versus the New Space Opera. Voice of Youth Advocates 31: 132-33.

Little, Judith A. 2007. Feminist Philosophy and Science Fiction: Utopias and Dystopias. New York: Prometheus Books. Macaulay, Rose. 1918. What Not: A Prophetic Comedy. London: Constable.

Martínez-Falquina, Silvia. 2019. “Louise Erdrich's Future Home of the Living God: Uncertainty, Proleptic Mourning and Relationality in Native Dystopia". Atlantis: Journal of the Spanish Association of Anglo-American Studies 41: 161-78. [CrossRef]

Meacham, Steve. 2011. Space Opera Supremo. The Sydney Morning Herald. July 24. Available online: https://www. smh.com.au/entertainment/books/space-opera-supremo-20110723-1hu10.html (accessed on 11 April 2020).

Merrick, Helen. 2009. The Secret Feminist Cabal. A Cultural History of Science Fiction Feminisms. Seattle: Aqueduct Press.

Mitchison, Naomi. 1935. We Have Been Warned. London: Constable.

Mitchison, Naomi. 1962. Memoirs of a Spacewoman. London: Victor Gollancz Ltd.

Mitchison, Naomi. 1975. Solution Three. London: Dobson.

Nies, Betsy. 2002. Eugenic Fantasies: Racial Ideology in the Literature and Popular Culture of the 1920s. New York: Routledge.

Noyce, Philip. 2002. Rabbit Proof Fence.

O'Reilly, Andrea. 2014. Ain't I a Feminist?: Matricentric Feminism, Feminist Mamas, and Why Mothers Need a Feminist Movement/Theory of Their Own. Available online: https://mommuseum.org/aint-i-a-feminist-matricentricfeminism-feminist-mamas-and-why-mothers-need-a-feminist-movementtheory-of-their-own/ (accessed on 16 March 2020).

O'Reilly, Andrea. 2016. Matricentric Feminism: Theory, Activism, and Practice. Bradford: Demeter Press.

Perkins Gilman, Charlotte. 1915. Herland. New York: Pantheon Books. 
Pierce, Alexandra. 2010. 2010 Snapshot Archive: Marianne de Pierres. Australian SF Snapshot Project. Available online: https://austsfsnapshot.wordpress.com/2016/05/30/2010-snapshot-archive-marianne-depierres/ (accessed on 16 March 2020).

Pilkington, Doris. 1996. Follow the Rabbit-Proof Fence. St Lucia: University of Queensland Press.

Rich, Adrienne. 1976. Of Woman Born: Motherhood as Experience and Institution. New York: Norton.

Russ, Joanna. 2007. The Country You Have Never Seen: Essays and Reviews. Liverpool: Liverpool University Press.

Sheldon, Rebeca. 2016. The Child to Come. Life after the Human Catastrophe. Minneapolis: University of Minnesota Press.

Stankow-Mercer, Naomi. 2009. Dystopias. In Women in Science Fiction and Fantasy. Edited by Robin Anne Reid. London: Greenwood Press, pp. 91-92.

Stanworth, Mary. 1987. Reproductive Technologies: Gender, Motherhood and Medicine. Cambridge: Polity Press.

Stone, Leslie F. 1931. "The Conquest of Gola". Wonder Stories; Mt. Morris, Illinois, April, pp. 1278-87. Available online: https://openpublishing.psu.edu/utopia/content/conquest-gola (accessed on 6 July 2020).

Watkins, Susan. 2020. Contemporary Women's Post-Apocalyptic Fiction. London: Palgrave Macmillan.

Weaver, Roslyn. 2011. Apocalypse in Australian Fiction and Film: A Critical Study. Jefferson: McFarland.

World Health Organization (WHO). 2015. WHO Statement on Caesarean Section Rates. Available online: https://apps.who.int/iris/bitstream/handle/10665/161442/WHO_RHR_15.02_eng.pdf?sequence=1 (accessed on 12 June 2020).

World Health Organization (WHO). 2018. Recommendation on Birth Position. February 17. Available online: https://extranet.who.int/rhl/topics/preconception-pregnancy-childbirth-and-postpartum-care/care-duringchildbirth/care-during-labour-2nd-stage/who-recommendation-birth-position-women-without-epiduralanalgesia (accessed on 10 June 2020).

Wilson, Scott. 2010. Book Review: Chaos Space. The Sentients of Orion, Book Two, by Marianne de Pierres. The Fringe. November 10. Available online: http://thefringemagazine.blogspot.com/2010/11/book-reviewchaos-space-sentients-of.html (accessed on 10 May 2020).

Winter, Jerome. 2016. Science Fiction, New Space Opera, and Neoliberal Globalism: Nostalgia for Infinity. Cardiff: University of Wales Press.

Wolfe, Gary K. 2014. “Literary Movements". In The Oxford Handbook of Science Fiction. Edited by Ro Latham. Oxford: Oxford University Press, pp. 59-70.

Yaszek, Lisa. 2006. From Ladies' Home Journal to the Magazine of Fantasy and Science Fiction: 1950s SF, the Offbeat Romance Story, and the Case of Alice Eleanor Jones. In Daughters of the Earth. Feminist Science Fiction in the Twentieth Century. Edited by Justine Larbalestier. Middletown: Wesleyan University Press, pp. 76-96.

Yaszek, Lisa, ed. 2018. The Future is Female! New York: Library of America.

(C) 2020 by the author. Licensee MDPI, Basel, Switzerland. This article is an open access article distributed under the terms and conditions of the Creative Commons Attribution (CC BY) license (http://creativecommons.org/licenses/by/4.0/). 